\title{
Prevalence and Predictors of Vitamin D Insufficiency in Adolescents Living at an Intermediate Altitude \\ M Konak ${ }^{2}, \mathrm{H} \mathrm{Alp}^{3}, \mathrm{Z} \mathrm{Orbak}^{4}$, B Ozkan4
}

\begin{abstract}
Although vitamin D insufficiency is very common health problem in the world, its prevalence and predictors in adolescents are controversial. We planned to evaluate prevalenve and predictors of vitamin D insufficiency in adolescents living at an intermediate altitude. We also want to give optimal serum $25(\mathrm{OH})$ vitamin D levels in relation to serum PTH levels.

This study was conducted at 343 primary and high school children aged between 1317 years living in Erzurum city center. These children were selected using stratified random sampling in the spring (April-May), and were invited to our department for participation in this research study. Of 343 children, 246 could be evaluated again in the autumn (SeptemberOctober). Subjects with vit D level $<10 \mathrm{ng} / \mathrm{ml}$ were considered as vitamin D deficiency, and with $10-20 \mathrm{ng} / \mathrm{ml}$ as vitamin D insufficiency. If vitamin D level is $>20 \mathrm{ng} / \mathrm{ml}$, it's considered as adequate. In spring, vitamin D deficiency was detected in $17.7 \%$ and vitamin D insufficiency was detected in $72 \%$ of subjects. At the end of summer these rates were 1.6 $\%$ and $41.1 \%$ respectively. Serum 25(OH)vitamin D levels at which plasma PTH concentrations begin to form a plateau is $22 \mathrm{ng} / \mathrm{mL}$. Values below estimated lower normal level $(22 \mathrm{ng} / \mathrm{mL})$ were detected in $94.2 \%$ of subjects.
\end{abstract}

Key words: adolescent rickets, altitude, parathyroid hormone, risk factors, prevalence

From: Ataturk University Medical Faculty Department of Paediatrics 25240, Erzurum, Turkey.

Correspondence: Dr Z Orbak, Ataturk University Medical Faculty Department of Paediatrics 25240, Erzurum, Turkey. E-mail: zerrinorbak@yahoo.com 
We believe that vitamin D prophylaxis could be given to all adolescents as well as regulation of lifestyle. Our results will increase awareness for vitamin D deficiency and insufficiency in adolescents and inform future public health preventative strategies.

\section{INTRODUCTION}

Vitamin D, a fat-soluble vitamin is essential for normal calcium metabolism. Vitamin D deficiency has been linked to osteoporosis, hypertension, cardiovascular diseases, multiple sclerosis, diabetes mellitus, infectious diseases, autoimmune diseases and several cancers (1). The vitamin D status is usually evaluated by measuring the level of $25(\mathrm{OH})$ vitamin $\mathrm{D}$ in serum.

Although vitamin D insufficiency is very common health problem in the world, its prevalence and predictors in adolescents are controversial. This discrepency is associated with the absence of consensus on the optimal concentrations of serum $25(\mathrm{OH})$ vitamin $\mathrm{D}$. The major sources of vitamin D in humans are sun exposure to ultraviolet B radiation, and small amounts $(<10 \%)$ obtained from diet and supplementation (2). The annual fluence of UVB is very effective in the low latitude and high altitude areas. There is less filtration of UVB by the atmosphere as compared with sea level. Our region (Erzurum, Turkey) is located 39 degrees north of the aquator (borderline latitude) and $1900 \mathrm{~m}$ above sea level (intermediate altitude). Sun exposure and clothing habits and geographic properties (differences in fluence rates of UVB from place to place) are likely major determinants on vitamin $\mathrm{D}$ status. We planned to evaluate prevalenve and predictors of vitamin $\mathrm{D}$ insufficiency in adolescents living at an intermediate altitude. We also recommend optimal serum 25(OH) vitamin D levels in relation to serum PTH levels. So, these will form the basis for recommendations for preventing vitamin D insufficiency in Turkey. 


\section{MATERIALS AND METHODS}

Informed consent was obtained from parents. This study was approved by the Ethics Committee of the Faculty of Medicine, Atatürk University.

\section{Study site and participants}

This study was conducted at 397 primary and high school children aged between 13-17 years living in Erzurum city center. These children were selected using stratified random sampling in the spring (April-May), and were invited to our department for research. Of 397 children, $369(92,9 \%)$ accepted to participate in the study. During evaluation 23 children were excluded from the study. Of 343 children, 246 could be evaluated during follow-up visit in the autumn (September-October). Subjects were excluded from the study if they had used any relevant medications during the last six months (calcium, vitamin $\mathrm{D}$ and drugs known to affect calcium and vitamin D metabolism (anticonvulsant, heparin, corticosteroid etc)) or the last 1 year (antiresorptive or anabolic) prior to the study. Other exclusion criteria were the presence of diseases that affected calcium and vitamin D metabolism such as metabolic diseases (diabetes mellitus, hypo-hyperthyroidism), renal and gastrointestinal disorders. Children with recent fracture, illness that required bed rest or inhibited outdoor play were excluded. All children included in the study were not given any vitamin D supplement during the duration of study and they were healthy. The participants were white.

\section{Demography and sampling}

Firstly, questionnaire was administered to the child and physical examination was performed. After that a fasting venous blood sample withdrawn for biochemical analysis at the first visit in the spring. Physical examination and biochemical evaluation were repeated again in the autumn.

On questionnaire child's age, parent's education, income, clothing habits, and whether multivitamin use were documented. Dietary, physical activity and outdoor stay time records 
were evaluated using questionnaire. The nutritionist helped to evaluate the mean calcium intake daily (mg/day) according to the seven-day dietary recall data because low dietary caicium intakes might play a role in the pathogenesis of rickets in this age group. The information for physical activity (min/day) and outdoor stay time (min/day) was also assessed from a seven-day diary data.

Weight and height measurements, and Tanner staging were performed using the same equipment and by the same observer. All of them were in Tanner stage IV and V. Subjects were naked when weight. BMI (body mass index) was calculated as $\left[\mathrm{kg} / \mathrm{m}^{2}\right]$.

Overnight fasting blood samples were taken from all subjects for determinations of serum 25(OH) vitamin D and plasma intact PTH levels. Serum 25(OH) vitamin D levels were measure by chemiluminescent assay (Roche Diagnostic GmbH Mainheim/Germany). Serum intact PTH levels were determined by 2-step chemiluminescent assay (Beckman Coulter Access Intact PTH (iPTH), Galway, Ireland).

Although there is no consensus regarding the different ranges of sufficiency and insufficiency levels of $25(\mathrm{OH})$ vitamin $\mathrm{D}$ in the serum, in the present study we defined vitamin $\mathrm{D}$ deficiency as level of $25(\mathrm{OH})$ vitamin $\mathrm{D}$ below $10 \mathrm{ng} / \mathrm{mL}$ and vitamin $\mathrm{D}$ insufficiency was defined as levels below $20 \mathrm{ng} / \mathrm{mL}(1,2)$.

Statistical analysis was conducted with the SPSS/PC program, version 15.0 statistics were calculated for each variable. Categorical data were summarized with percentages and frequencies. Continous data were presented as means \pm SD. Variables were evaluated by student $t$ test, Mann-Whitney $\mathrm{U}$ test, Chi-square and Kruskal Wallis, Fisher test and Spearman test. Two-tailed tests were used throughout. A p value of $<0.05$ was considered significant. 


\section{RESULTS}

The mean age of all children was $15.44+1.28$ years (13-17 years). Of all children, 198 (57.7 $\%)$ were male, $145(42.3 \%)$ were female in the spring. Frequency and mean values of vitamin D deficiency and sufficiency according to sex and season were given in Table 1 and Table 2, respectively. Serum $25(\mathrm{OH})$ vitamin D level in females was normal in just 2 cases (1.4\%) in spring. Of males, $16.7 \%$ were normal. Frequencies of vitamin D deficiency and sufficiency were quite high for both sexes in spring after winter. In males, both mean serum $25(\mathrm{OH})$ vitamin D levels and frequency of normal vitamin D levels were significantly higher in fall than those in spring $(\mathrm{p}<0.05)$ (Table 1). Although no child took oral vitamin $\mathrm{D}$, after summer, mean serum $25(\mathrm{OH})$ vitamin D levels significantly increased while frequency of insufficienciencies or deficiencies decreased in fall.

Sociodemographic properties of children according to vitamin D status at the admission were shown in Table 2. Income, parent's education level, number of family members, use vitamin D in the first year of life did not significantly affect frequency vitamin D deficiency and insuffiency.

Height, weight, BMI measurements of adolescents did not correlate with serum vitamin D levels. Mean oral calcium intake, outdoor stay time and physical activity time of adolescents were given in Table 3. Mean oral Ca intakes of groups were similar ( $>0.05)$. Mean outdoor time and physical activity times were lower in females than males in both spring and autumn.

When clothing habit of females was evaluated, mean vitamin D levels were not different between groups (Table 4). Frequency of normal vitamin D level increased to $46.7 \%$ in adolescents who did not wear islamic style after summer. On the other hand, it was just $19.2 \%$ in adolescents wearing islamic style. 
Complaints of adolescents regarding muscle pain or bone or joint pain were given in Table 5. Muscle pain in vitamin D deficient and sufficient adolescents was significantly frequent complaint compared to controls $(\mathrm{p}<0.05)$. There was an inverse linear correlation between serum 25(OH) vitamin D and PTH levels in both spring and autumn $(\mathrm{p}<0.05)$ (Figure 1). Serum 25(OH)vitamin D levels at which plasma PTH concentrations begin to form a plateau is $22 \mathrm{ng} / \mathrm{mL}$ (Figure 2). Values below estimated lower normal level (22 $\mathrm{ng} / \mathrm{mL}$ ) were detected in $94.2 \%$ of subjects.

\section{DÍSCUSSION}

Vitamin D insufficiency in adolescents results from insufficiently sun exposure and receiving inadequate vitamin $\mathrm{D}$ and increased requirements secondary to rapid growing in pubertal period $(3,4)$. To our knowledge, our study is the most extensive epidermiological study to report the prevalence of vitamin D insufficiency in adolescents.

Absoud et al (5) found that 35.1\% of children aged 4-18 in Great Britain were vitamin D insufficient (vitamin D levels: < 20ng/ml) and there was no significant gender difference. In sunny environment of Israil (latitude $30-33^{\circ} \mathrm{N}$ ) mean serum vitamin D levels were $22.9+10.1 \mathrm{ng} / \mathrm{ml}$ and percentage of insufficient vitamin D was $78 \%$ (6). Liang et al (7) also found that $28.3 \%$ had vitamin D levels in infants in San Diego (latitude 38 degrees) . Szalay et al (8) also demonstrated that $14 \%$ of children living in a sunny climate had vitamin D levels $<20 \mathrm{ng} / \mathrm{mL}$. According to these studies a sunny climate does not assure vitamin D sufficiency. There were different frequencies in literature, so vitamin D levels relate to many factors. In our country, in different city, Van, 25(OH)D3 levels was normal in $47.6 \%$ of adolescents (9). Frequency of adolescent rickets was higher in females and 25(OH)D3 levels were lower in the covered girls (9). Our high prevalence can be related to clothing habits and 
lifestyle such as less exposure to sunlight due to shorter outdoor stay time and physical activity. Nowadays, the time that children play outside is diminishing. A study in Minnesota reported that $40 \%$ of children regularly watch television by age 3 months, and that found $90 \%$ by age 2 (10). Children from 2 to 17 years of age spend almost 6 hours per day with electronic media (11). Another study also reported that $<18 \%$ children aged 9 to 15 years walk to school even 1 day per week (12). Children who spent more time doing outdoor exercise (at least an hour/day/week) and less time waching TV per day ( $<2.5$ hours) also higher vitamin D levels (5). Both from the literature and from our study, it is apparent that the major effect on vitamin D levels seems to come from vitamin D supplementation and outdoor lifestyle and physical activity. This modern lifestyle may result in lower vitamin D levels that threaten bone health for a lifetime.

Classically, vitamin D insufficiency is associated with high latitude and high altitude. Latitude is attributed to reduced ultraviolet radiation exposure in areas far from the equator (1). However, several studies like our study showed that this problem is not limited to sundeprivated regions of the world. So, other risk factors causing vitamin D insufficiency must be demonstrated quite well for maintenance of optimal health. At higher altitudes, a thinner atmosphere filters less UV radiation. With every 1000 metres increase in altitude, UV levels increase by 10 to $\% 12 \%$ (13). Recently, Holick et al (14) reported the effects of altitude on previtamin D3 synthesis. Norsang et al (15) found that the average vitamin D status was similar although the annual dose of vitamin D-generating UVB is about five times larger in Lhasa (in Tibet, lalitude: 29 , altitude: $3670 \mathrm{~m}$ ) than in Oslo. In Guatemalan, at $2333 \mathrm{~m}$ above sea level, $46.3 \%$ had values below $20 \mathrm{ng} / \mathrm{ml}$ (16). These and our results suggested that altitude is probably not major factor, as people exposure only face and hands, and they don't stay enough time outdoor. 
Different studies showed that vitamin D levels declined and insufficiency rates rose as the age increased $(5,6)$. We did not find correlation between age and vitamin D levels. It might be related to the narrow age range in our study.

The 25(OH)vitamin D level has not been standardized. There was no consensus what cutoff criteria define deficient, low, or adequate/optimal $25(\mathrm{OH})$ vitamin D level. Vitamin D insufficiency is defined by most experts as a serum $25(\mathrm{OH})$ vitamin D level $<20 \mathrm{ng} / \mathrm{ml}$ $(1,2,6,14,17)$. It is suggested that optimal range of $25(\mathrm{OH})$ vitamin $\mathrm{D}$ for skeletal health is level that reduces PTH levels to a minimum (18). Vitamin D deficiency is accepted to contribute to bone loss by stimulating PTH secretion. In 2009, Bacon et al (19) found that vitamin D supplementation was only able to suppress parathyroid hormone levels in older individuals with baseline vitamin D levels less than $20 \mathrm{ng} / \mathrm{m}$. Data in adults demonstrates evidence of impaired calcium absorption and lower bone density at levels < $32 \mathrm{ng} / \mathrm{mL}$ (20). Optimal level of $25(\mathrm{OH})$ vitamin D have been based on estimates of the level of $25(\mathrm{OH})$ vitamin D required to minimize PTH levels. Increased PTH levels are usually seen with 25(OH)vitamin D levels < 40ng/mL (14). Singhellakis et al (21) researched the lower normal levels of $25(\mathrm{OH})$ vitamin D by using a vitamin D loading test in a normal adults, and found that basal serum $25(\mathrm{OH})$ vitamin D levels $>22 \mathrm{ng} / \mathrm{mL}$ should be considered as a vitamin $\mathrm{D}$ sufficient. In that study it was reported $57.7 \%$ of adults had vitamin D insufficient $(<22$ ng/mL) (21). In another study, Bacon et al (19) reported that PTH and P1NP (procollagen type 1 amino-terminal propeptide) were only suppressed by vitamin D treatment in those with baseline $25(\mathrm{OH})$ vitamin D levels $<50$ and $<30 \mathrm{nmol} / \mathrm{L}$, respectively. It should be underlined that low levels of $25(\mathrm{OH})$ vitamin $\mathrm{D}(<22 \mathrm{ng} / \mathrm{mL})$ were observed in most of the all studied children $(94.2 \%)$ in our study. The minimum value for vitamin D insufficiency definition is quite close, namely 20 vs $22 \mathrm{ng} / \mathrm{mL}$ in our study. However, $5.8 \%$ or $10.3 \%$ of adolescents had normal vitamin D levels if lower normal serum 25(OH)vitamin D level was accepted as 
$20 \mathrm{ng} / \mathrm{mL}$ or $22 \mathrm{ng} / \mathrm{mL}$, respectively. So, we recommend that cutt-of value for serum $25(\mathrm{OH})$ vitamin D must be $22 \mathrm{ng} / \mathrm{mL}$ according to these results. Further corroboration of these results is needed.

Although Saliba et al (22) found the threshold $46.2 \mathrm{nmol} / \mathrm{L}(\approx 18.6 \mathrm{ng} / \mathrm{mL})$, Thomas et al (23) suggested $15 \mathrm{ng} / \mathrm{mL}$ to define vitamin D sufficiency for PTH stabilization.

In the literature, musculoskeletal pain has been reported (24). The distinction vitamin D sufficient adolescents is not easy because most vitamin D deficient children have no symptom and signs.

This study's results confirm the high prevalence of vitamin D deficiency and insufficiency among adolescents living at the intermediate altitude and sunny city. Our findings also showed that females had an increasing risk of vitamin D insufficiency. The percentage of abnormally low serum $25(\mathrm{OH})$ vitamin D levels in our group is unexpectedly high for a region with a temperate climate and at a relatively low northern lalitude $\left(39^{\circ} \mathrm{N}\right)$.

This study also suggests that a sunny climate and high altitude does not quarantee adequate vitamin D levels. Vitamin D supplemantation should be routine during adolecence. We believe that vitamin D prophylaxis could be given to all adolescents as well as regulation of lifestyle. Our results will increase awareness for vitamin D deficiency and insufficiency in adolescents and inform future public health preventative strategies one more time. 


\section{REFERENCES}

1. Lanham-New SA, Buttriss JL, Miles LM, Ashwell M, Berry JL, et al. Proceedings of the Rank Forum on vitamin D. Br J Nutr 2011; 105: 144-156.

2. Misra M, Pacaud D, Petryk A, et al. Drug and Therapeutics Committee of the Lawson Wilkins Pediatric Endocrine Society. Vitamin D deficiency in children and its management: review of current knowledge and recommendations. Pediatrics 2008; 122: 398-417.

3. Looker AC, Dawson-Hughes B, Calvo MS, Gunter EW, Sahyoun NR. Serum 25hydroxyvitamin D status of adolescents and adults in two seasonal subpopulations from NHANES III. Bone 2002; 30: 771-7.

4. Freycon MT, Pouyau G, Abeille A, et al. Deficiency rickets in older children. Apropos of 2 cases. Pediatrie 1983; 38: 485-90.

5. Absoud M, Cummins C, Lim MJ, Wassmer E, Shaw N. Prevalance and predictors of vitamin D insufficiency in children: A Great Britain Population based study. PLos One 2011; 6(7): 1-6.

6. Oren Y, Shapira Y, Agmon-Levin N, et al. Vitamin D insufficiency in a sunny environment: A demographic and seasonal analysis. IMAJ 2010; 12: 751-6.

7. Liang L, Chantry C, Styne DM, et al. Prevalence and risk factors for vitamin D deficiency among healthy infants and young children in Sacramento, California. Eur J Pediatr 2010; 169 (11): 1337-44. 
8. Szalya EA, Tryon EB, Pleacher MD, Whisler SL. Pediatric vitamin D deficiency in a southwestern luminous climate. J Pediatr Orthop 2011; 31(4): 469-73.

9. Uner A, Acar MN, Cesur Y, et al. Rickets in healthy adolescents in Van, the eastern of Turkey. Eur J Gen Med 2010; 7(1): 69-75.

10. Mitchell AA. TV and other electronic media: how widely are they used? Child Health Alert 2007; 25: 4 .

11. Jordan A. The role of media in children's development: an ecological perspective. Dev Behav Pediatr 2004; 25: 196-206.

12. Martin SL, Lee SM, Lowry L. National prevalence and correlates of walking and bicycling to school. Am J Prev Med 2007; 33: 98-105.

13. www.who.int/uv/uv_and_health/en/

14. Holick MF. Vitamin D deficiency. N Engl J Med 2007; 357: 266-81.

15. Norsang G, Ma L, Dahlback A et al. The vitamin D status among Tibetans. Photochemistry and photobiology 2009; 85: 1028-31.

16. Sud SR, Montenegro-Bethancourt G, Bermudez OI, Heaney RP, Armas L, Solomons NW. Older Mayan residents of the western highlands of Guatemala lack sufficient levels of vitamin D. Nutrition Res 2010; 30: 739-46.

17. Cashman KD, Hill TR, Cotter AA, Boreham C. et all. Low vitamin D status adversely affects bone health parameters in adolescents. Am J Clin Nutr 2008; 87: 1039-44.

18. Holick MF. High prevalence of vitamin D inadequacy and implications for health. Mayo Clin Proc 2006; 81: 353-73.

19. Bacon CJ, Gamble GD, Horne AM, Scott MA, Reid IR. High-dose oral vitamin D3 supplementation in the elderly. Osteoporosis Int 2009; 20: 1407-15.

20. Heany RP, Dowell MS, Hale CA, et al. Caicium absorption varies within the reference range for serum 25-hydroxyvitamin D. J Am Coll Nutr 2003; 22: 142-6. 
21. Singhellakis PN, Malandrinou FC, Psarrou CJ, Daneli AM, Tsalavoutas SD, Constandellou ES. Vitamin D deficiency in white, apparently healthy, free-living adults in a temperate region. Hormones $2011 ; 10(2): 131-43$.

22. Saliba W, Barnett O, Rennert HS, Lavi I, Rennert G. The relatioship between serum 25(OH)D and parathyroid hormone levels. Am J Med 2011; 124: 1165-70.

23. Thomas MK, Lloyd-Jones DM, Thadhani RI, et al. Hypovitaminosis D in medical inpatients. N Engl J Med 1998; 338: 777-83.

24. Plotnikoff GA, Quigley JM. Prevalence of severe hypovitaminosis D in patients with persistent, nonspecific musculoskeletal pain. Mayo Clinic Proc 2003; 78: 1463-70. 
Orbak et al

Table 1. Frequency and mean of serum vitamin D levels in vitamin D deficiency and sufficiency according to sex and season

\begin{tabular}{|c|c|c|c|c|c|c|c|c|c|c|c|c|c|c|c|c|c|c|c|}
\hline & \multicolumn{9}{|c|}{ Spring } & \multicolumn{10}{|c|}{ Autumn } \\
\hline & \multirow[t]{2}{*}{ Sex } & \multicolumn{2}{|c|}{ Deficiency } & \multicolumn{2}{|c|}{ Sufficiency } & \multicolumn{2}{|c|}{ Normal } & \multicolumn{2}{|c|}{ Total } & \multirow[t]{2}{*}{$\mathbf{p}$} & \multicolumn{2}{|c|}{ Deficiency } & \multicolumn{2}{|c|}{ Sufficiency } & \multicolumn{2}{|c|}{ Normal } & \multicolumn{2}{|c|}{ Total } & \multirow[t]{2}{*}{$\mathbf{p}$} \\
\hline & & $\mathbf{n}$ & $\%$ & $\mathbf{n}$ & $\%$ & $\mathbf{n}$ & $\%$ & $\mathbf{n}$ & $\%$ & & $\mathbf{n}$ & $\%$ & $\mathbf{n}$ & $\%$ & $\mathbf{n}$ & $\%$ & $\mathbf{n}$ & $\%$ & \\
\hline \multirow{3}{*}{$\begin{array}{l}\text { Frequenc } \\
y\end{array}$} & Female & 53 & 36.5 & 90 & 62.1 & 2 & 1.4 & 145 & 42.3 & $<0.05$ & 4 & 4.2 & 70 & 73.6 & 21 & 22.2 & 95 & 38.6 & $<0.05$ \\
\hline & Male & 8 & 4.0 & 157 & 79.3 & 33 & 16.7 & 198 & 57.7 & $<0.05$ & 0 & - & 31 & 20.5 & 120 & 79.5 & 151 & 61.4 & $<0.05$ \\
\hline & Total & 61 & 17.7 & 247 & 72.0 & 35 & 10.3 & 343 & 100 & $<0.05$ & 4 & 1.6 & 101 & 41.0 & 141 & 57.4 & 246 & 100 & $<0.05$ \\
\hline Vitamin & Female & \multicolumn{2}{|c|}{$8.4 \pm 1.2$} & \multicolumn{2}{|c|}{$13.1 \pm 2.3$} & \multicolumn{2}{|c|}{$23.8 \pm 3.2$} & \multicolumn{2}{|c|}{$11.6 \pm 3.3$} & $<0.05$ & \multicolumn{2}{|c|}{$8.7 \pm 0.9$} & \multicolumn{2}{|c|}{$14.8 \pm 2.6$} & \multicolumn{2}{|c|}{$23.4 \pm 2.7$} & \multicolumn{2}{|c|}{$16.1 \pm 4.5$} & $<0.05$ \\
\hline \multirow[t]{2}{*}{ D level } & Male & \multicolumn{2}{|c|}{$8.7 \pm 1.7$} & \multicolumn{2}{|c|}{$15.8 \pm 2.8$} & \multicolumn{2}{|c|}{$23.3 \pm 2.7$} & \multicolumn{2}{|c|}{$16.7 \pm 4.2$} & $<0.05$ & & - & \multicolumn{2}{|c|}{$17.1 \pm 2.3$} & \multicolumn{2}{|c|}{$25.1 \pm 3.6$} & \multicolumn{2}{|c|}{$23.3 \pm 4.8$} & $<0.05$ \\
\hline & Total & \multicolumn{2}{|c|}{$8.5 \pm 1.2$} & \multicolumn{2}{|c|}{$14.8 \pm 2.9$} & \multicolumn{2}{|c|}{$23.3 \pm 2.9$} & \multicolumn{2}{|c|}{$14.5 \pm 4.6$} & $<0.05$ & \multicolumn{2}{|c|}{$8.7 \pm 0.9$} & 15.5 & & 24. & \pm 3.6 & 20 & \pm 5.8 & $<0.05$ \\
\hline
\end{tabular}

Kruskal Wallis test 
Table 2. Sociodemographic properties of children according to vitamin D status at the admission

\begin{tabular}{|c|c|c|c|c|c|c|c|}
\hline \multirow[b]{2}{*}{ Property } & \multicolumn{2}{|c|}{ Deficiency } & \multicolumn{2}{|c|}{ Sufficiency } & \multicolumn{2}{|c|}{ Normal } & \multirow[b]{2}{*}{$\mathbf{p}$} \\
\hline & n:61 & $\%$ & $\mathrm{n}: 247$ & $\%$ & n:35 & $\%$ & \\
\hline Age (year) & $15.8 \pm 1.2$ & & $15.3 \pm 1.3$ & & $15.6 \pm 1.4$ & & 0.06 \\
\hline \multicolumn{8}{|l|}{ Sex } \\
\hline Female & 53 & 36.5 & 90 & 62.1 & 2 & 1.4 & \\
\hline Male & 8 & 4.0 & 157 & 79.3 & 33 & 16.7 & 0.00 \\
\hline \multicolumn{8}{|l|}{ Father's education } \\
\hline Illiterate & 1 & 9.1 & 9 & 81.8 & 1 & 9.1 & \\
\hline Primary school & 57 & 20.3 & 194 & 69.0 & 30 & 10.7 & 0.83 \\
\hline High school & 3 & 5.9 & 44 & 86.3 & 4 & 7.8 & \\
\hline \multicolumn{8}{|l|}{ Mother's education } \\
\hline Illiterate & 13 & 20.3 & 44 & 68.7 & 7 & 10.9 & \\
\hline Primary school & 47 & 8.2 & 497 & 87.1 & 27 & 4.7 & 0.13 \\
\hline High school & 1 & 12.5 & 6 & 75.0 & 1 & 12.5 & \\
\hline \multicolumn{8}{|l|}{ Mother's job } \\
\hline Housewife & 61 & 18.3 & 238 & 71.5 & 34 & 10.2 & \\
\hline Business women & 0 & 0 & 9 & 90.0 & 1 & 10.0 & 0.91 \\
\hline \multicolumn{8}{|l|}{ No of family member } \\
\hline $3-4$ & 10 & 17.8 & 40 & 71.4 & 6 & 10.7 & \\
\hline $5-6$ & 33 & 16.3 & 148 & 73.3 & 21 & 10.4 & 0.58 \\
\hline 7 and up & 18 & 21.2 & 59 & 69.4 & 8 & 9.4 & \\
\hline \multicolumn{8}{|l|}{ Region of city } \\
\hline Rural & 48 & 19.9 & 166 & 68.8 & 27 & 11.3 & 0.24 \\
\hline Urban & 42 & 18.2 & 168 & 72.7 & 21 & 9.1 & \\
\hline \multicolumn{8}{|l|}{ Montly income } \\
\hline$<500 \mathrm{TL}^{*}$ & 13 & 21.3 & 42 & 68.8 & 6 & 9.8 & \\
\hline 500-1000 TL & 31 & 21.7 & 99 & 69.2 & 13 & 9.1 & 0.28 \\
\hline$>1000 \mathrm{TL}$ & 17 & 12.2 & 106 & 76.3 & 16 & 11.5 & \\
\hline \multirow{2}{*}{\multicolumn{8}{|c|}{$\begin{array}{l}\text { Use vitamin D in } \\
\text { first year of life }\end{array}$}} \\
\hline & & & & & & & \\
\hline Yes & 32 & 23.5 & 91 & 66.9 & 13 & 9.5 & \\
\hline No & 29 & 14.0 & 156 & 75.4 & 22 & 10.6 & 0.17 \\
\hline
\end{tabular}

Kruskal Wallis H

*TL: Turkish lira 
Table 3. Mean oral calcium intake, outdoor time and physical activity time of adolescents

Spring

Autumn

\begin{tabular}{lllllllll} 
& Female & Male & Total & $\mathbf{p}$ & Female & Male & Total & p \\
\hline $\begin{array}{l}\text { Oral Ca } \\
\text { intake(mg/day) }\end{array}$ & $381 \pm 113$ & $391 \pm 128$ & $387 \pm 122$ & $>0.05$ & $378 \pm 115$ & $394 \pm 129$ & $387 \pm 131$ & $>0.05$ \\
$\begin{array}{l}\text { Outdoor time } \\
\text { (min/day) }\end{array}$ & $46.9 \pm 9.5$ & $76.2 \pm 18.3$ & $66.5 \pm 30.6$ & $<\mathbf{0 . 0 5}$ & $87 \pm 17.9$ & $8 \pm 16.4$ & $100 \pm 29$ & $<\mathbf{0 . 0 5}$ \\
$\begin{array}{l}\text { Physical } \\
\begin{array}{l}\text { activity } \\
\text { (min/day) }\end{array}\end{array}$ & $22.9 \pm 11.5$ & $37.2 \pm 17$ & $31.2 \pm 16.5$ & $<\mathbf{0 . 0 5}$ & $37.2 \pm 17.2$ & $52.3 \pm 14$ & $5.9 \pm 17.2$ & $<\mathbf{0 . 0 5}$ \\
\hline
\end{tabular}

Mann-Whitney U

Table4. Distribution of clothing habit (islamic style) and vitamin D status in females

\begin{tabular}{|c|c|c|c|c|c|c|c|c|c|c|c|c|c|c|}
\hline & \multicolumn{14}{|c|}{ Season } \\
\hline & \multirow{2}{*}{\multicolumn{2}{|c|}{$\begin{array}{c}\text { No } \\
\text { islamic }\end{array}$}} & \multirow{2}{*}{\multicolumn{2}{|c|}{$\begin{array}{l}\text { Sprin } \\
\text { Islamic }\end{array}$}} & \multirow{2}{*}{\multicolumn{2}{|c|}{ Total }} & \multirow{3}{*}{$\mathbf{p}$} & \multirow{3}{*}{\multicolumn{2}{|c|}{$\begin{array}{c}\begin{array}{c}\text { No } \\
\text { islamic }\end{array} \\
\mathrm{n} \\
\%\end{array}$}} & \multirow{2}{*}{\multicolumn{2}{|c|}{$\begin{array}{l}\text { Autun } \\
\text { Islamic }\end{array}$}} & \multirow{2}{*}{\multicolumn{2}{|c|}{ Total }} & \multirow{3}{*}{$\mathbf{p}$} \\
\hline & & & & & & & & & & & & & & \\
\hline & $\mathrm{n}$ & $\%$ & $\mathrm{n}$ & $\%$ & $\mathrm{n}$ & $\%$ & & & & $\mathrm{n}$ & $\%$ & $\mathrm{n}$ & $\%$ & \\
\hline Vitamin & \multirow{2}{*}{\multicolumn{2}{|c|}{$12.5 \pm 4$}} & \multirow{2}{*}{\multicolumn{2}{|c|}{$11.4 \pm 3.1$}} & \multirow{2}{*}{\multicolumn{2}{|c|}{$11.6 \pm 3.3$}} & \multirow[t]{4}{*}{0.1} & & & & & \multicolumn{2}{|c|}{$16.3 \pm 4.5$} & 0.11 \\
\hline $\begin{array}{l}\text { D level } \\
(\mathrm{ng} / \mathrm{ml})\end{array}$ & & & & & & & & \multicolumn{2}{|c|}{$19.1 \pm 6.4$} & \multicolumn{2}{|c|}{$15.8 \pm 4.1$} & & & \\
\hline Deficienc & 8 & 32 & 4 & 37. & 5 & 36. & & 0 & 0 & 4 & 4.8 & 4 & 4.2 & \\
\hline $\mathbf{y}$ & & & 6 & 4 & 4 & 4 & & & & & & & & \\
\hline Insufficie & 1 & 6 & 7 & 61. & 9 & 62. & $1 *$ & & 53. & 6 & 75. & 7 & 72. & 0.04 \\
\hline ncy & 7 & 8 & 5 & 0 & 2 & 2 & & 8 & 3 & 3 & 9 & 1 & 4 & $*$ \\
\hline Normal & 0 & 0 & 2 & 1.6 & 2 & 1.3 & & & 46. & 1 & 19. & 2 & 23. & \\
\hline & & & & & & & & 7 & 7 & 6 & 2 & 3 & 4 & \\
\hline
\end{tabular}

Mann-Whitney U and Chi-Square Test

* Fisher test 
Table 5. Complaints of adolescents

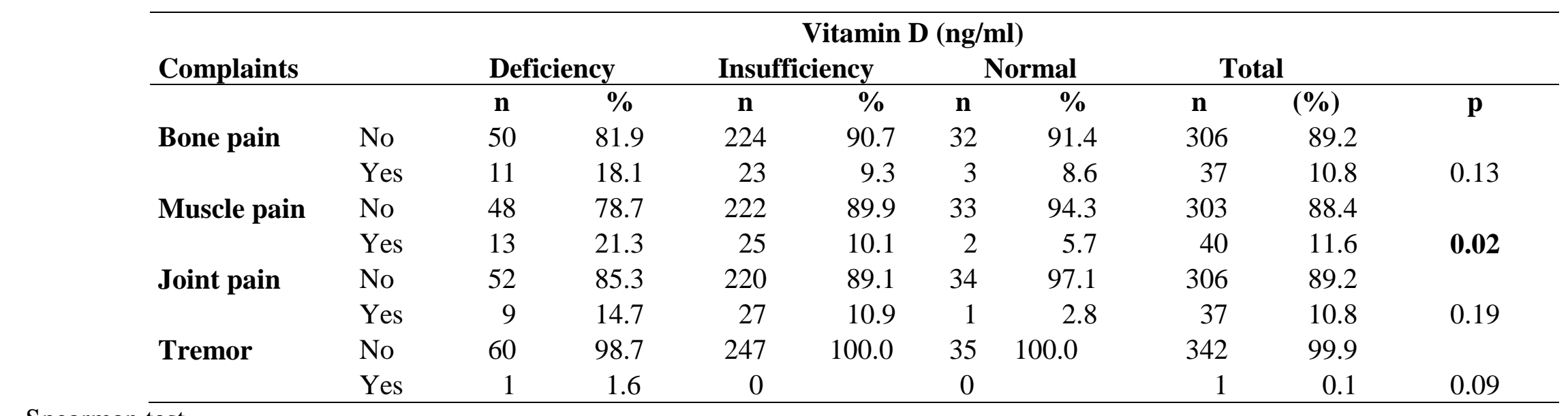

Spearman test 
Orbak et al

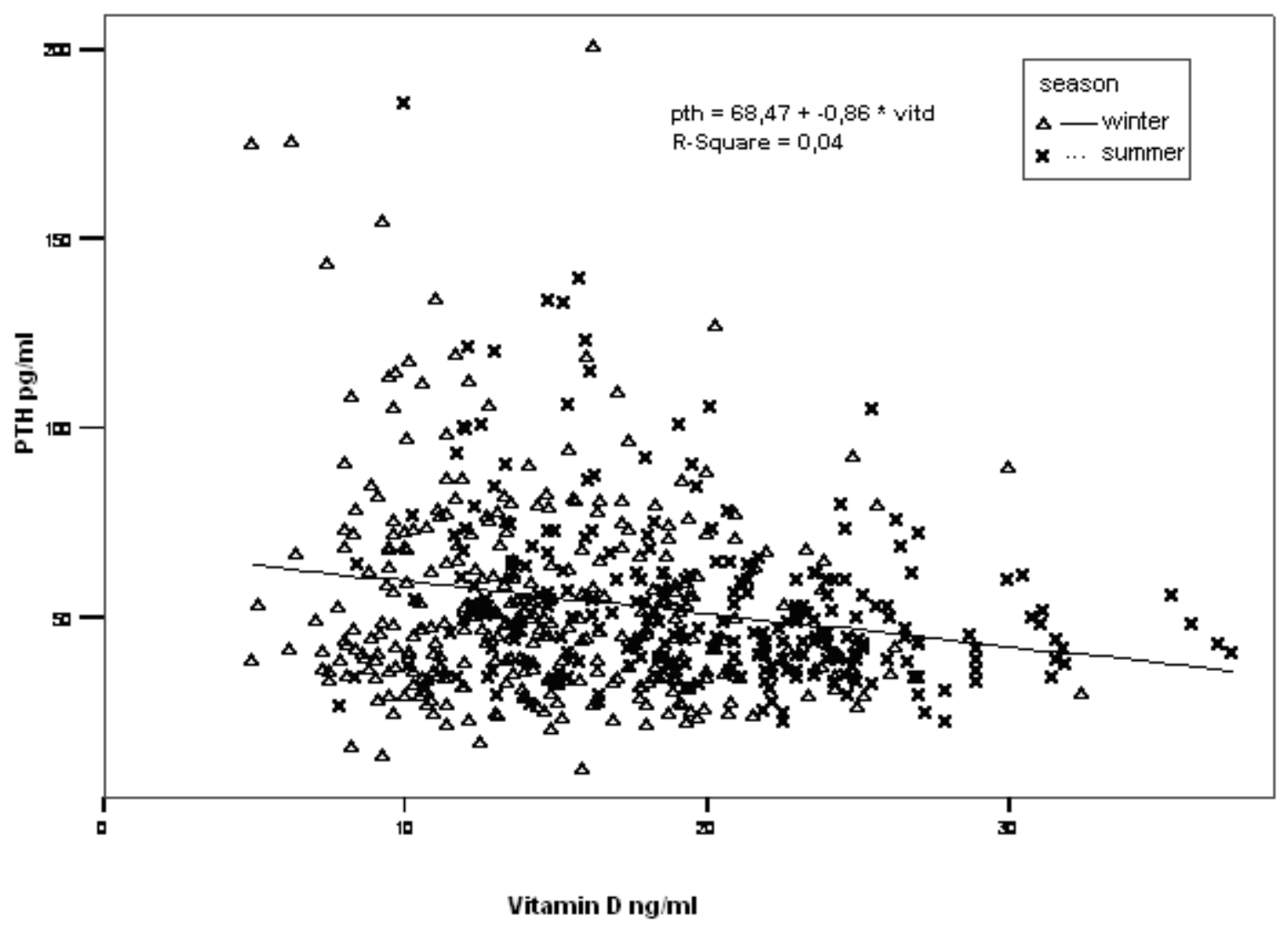

Figure 1. Significant negative linear correlation between serum intact PTH and 25(OH)vitamin D levels 
Prevalence and Predictors of Vitamin D Insufficiency in Adolescents



Figure 2. Serum 25(OH)vitamin D levels at which plasma PTH concentrations begin to form a plateau 


\section{Corresponding address:}

Prof. Dr. Zerrin Orbak

Ataturk University Medical Faculty Department of Pediatrics 25240, Erzurum, Turkey zerrinorbak@yahoo.com

*Ataturk University Medical Faculty Erzurum, Turkey.

**Pediatrician

****Professor of Pediatrics

*****Professor of Pediatrics, Pediatric Endocrinologist

Short title: Prevalence and Predictors of Vitamin D insufficiency in Adolescents

Brief synopsis: We evaluate vitamin D insufficiency in adolescents living at an intermediate altitude; and optimal serum $25(\mathrm{OH})$ vitamin D levels in relation to serum PTH levels. In spring, vitamin D deficiency was detected in $17.7 \%$ and vitamin D insufficiency was detected in $72 \%$ of subjects. At the end of summer these rates were $1.6 \%$ and $41.1 \%$ respectively. Serum 25(OH)vitamin D levels at which plasma PTH concentrations begin to form a plateau is $22 \mathrm{ng} / \mathrm{mL}$. 